\title{
Protektivitas, Reaksi Lokal dan Sistemik Pascaimunisasi dengan Vaksin Campak (Bio Farma) dari Bets Vaksin yang Berbeda pada Anak Sekolah Dasar di Sumatera Barat
}

\author{
Julitasari Sundoro, ${ }^{1}$ Novilia Sjafri Bachtiar, ${ }^{2}$ Syafriyal, ${ }^{3}$ Rini Mulia Sari ${ }^{2}$ \\ ${ }^{1}$ KOMNAS PP KIPI , 2PT. Bio Farma, Bandung., ${ }^{3}$ Subdit Imunisasi Kementrian Kesehatan Republik Indonesia
}

\begin{abstract}
Abstrak
Post Marketing Surveillance perlu dilakukan secara berkala untuk memastikan produk yang telah dipasarkan tetap dalam kualitas yang baik. Tujuan penelitian ini adalah mengetahui protektivitas, serta reaksi sistemik dan lokal setelah memperoleh dosis boster vaksin campak dari bets vaksin yang berbeda yang diproduksi pada fasilitas yang berbeda. Penelitian ini menggunakan desain kohort pada anak sekolah dasar di Sumatera Barat. Subjek di Kabupaten Agam mendapatkan vaksin dengan nomor bets 250210, sedangkan subjek di Kabupaten Limapuluh Kota vaksin campak bets 253080. Darah diambil sebelum dan 28 hari setelah imunisasi. Pengukuran antibodi menggunakan metode uji netralisasi dengan batas proteksi $\geq 200 \mathrm{mIU} / \mathrm{mL}$. Reaksi lokal dan sistemik dicatat pada kartu harian hingga 28 hari setelah imunisasi. Pengamatan berlangsung dari November 2010 hingga Maret 2011 melibatkan 170 anak di Kabupaten Agam dan 166 anak di Kabupaten Limapuluh Kota. Sebanyak 1,18-1.2\% anak mengalami demam pada 3 hari pertama setelah imunisasi dan $1(0,6 \%)$ timbul pada 14 hari setelah imunisasi dengan instensitas ringan. Reaksi lokal terbanyak adalah kemerahan pada tempat suntikan (14,46\%). Tidak ditemukan kejadian pascaimunisasi serius. Sejumlah 96,99\% dan 96,77\% anak mempunyai antibodi campak protektif 28 hari pascaimunisasi imunisasi di Kabupaten Agam dan Limapuluh Kota dengan kenaikan GMT dari 329,66 IU/mL menjadi 983,43 IU/mL dan dari 198,00 menjadi 535,10 IU/mL ( $\mathrm{p}=0,000$ ) di Kabupaten Agam dan Limapuluh Kota. Simpulannya adalah kedua bets vaksin campak menunjukkan keamanan dan respons imun yang baik. [MKB. 2015;47(3):144-51]
\end{abstract}

Kata kunci: Campak, Post Marketing Surveillance (PMS), reaksi lokal, reaksi sistemik, vaksin

\section{Protectiveness, Local Reaction, and Systemic Reaction after Measles Immunization using Different Batches of Bio Farma Vaccine in Elementary School Students in West Sumatra}

\begin{abstract}
Post Marketing Surveillance should be conducted periodically to monitor whether the quality of marketed products is still favorable. The objectives of this study were to evaluate the protectiveness, local reaction, and systemic reaction after receiving booster dose of measles vaccine from different batch numbers. This study was a cohort study on elementary students in West Sumatra. Subjects from Agam District received measles vaccine with a batch number of 250210 while subjects from Limapuluh Kota District received measles vaccine with a batch number of 253080. Blood samples were collected before and 28 days after immunization. Antibody titers were measured using neutralization assay with a protective level of $>200 \mathrm{mIU} / \mathrm{mL}$. Local and systemic reactions were recorded within 28 days after immunization. The observation was held from November 2010 to March 2011 and involved 336 students: 170 students from Agam District and 166 students from Limapuluh Kota District. There were 1.2\% students who experienced fever in the first three days after immunization, and $1(0.6 \%)$ student experienced mild fever 14 days after immunization. The most common local reaction was redness in the injection site, contributing approximately $14.48 \%$. There were no serious adverse events after immunization. About $96.99 \%$ and $96.77 \%$ students were protected against measles 28 days after immunization in Agam and Limapuluh Kota Districts with an increase in GMT from $329.66 \mathrm{IU} / \mathrm{mL}$ to $983.43 \mathrm{IU} / \mathrm{mL}$ and from $198.00 \mathrm{IU} / \mathrm{mL}$ to $535.10 \mathrm{IU} / \mathrm{mL}$ (p=0.000). In conclusion, both measles vaccine batches show good safety and immune response.. [MKB. 2015;47(3):144-51]
\end{abstract}

Key words: Local reaction, measles, Post Marketing Surveillance (PMS), systemic reaction, vaccine

Korespondensi: Dr. Julitasari Sundoro, dr., MSc-PH, Sekretariat Komite Nasional Pengkajian dan Penanggulangan Kejadian Ikutan Paska Imunisasi, Jl.Percetakan Negara No.29 Jakarta Pusat, mobile 0811142047, e-mail julitasari.sundoro@gmail.com 


\section{Pendahuluan}

Penelitian ini merupakan Post Marketing Surveillance (PMS) vaksin campak yang sudah lama dipasarkan. PMS perlu dilakukan secara berkala untuk menjamin bahwa kualitas produk tetap baik. Tujuan penelitian ini adalah menilai reaksi lokal dan reaksi sistemik pascaimunisasi satu dosis vaksin campak pada anak sekolah dasar. Respons imun yang dihasilkan juga akan dilihat dari dua nomor bets vaksin yang berbeda, dari fasilitas produksi yang berbeda diberikan pada dua daerah yang berbeda, yaitu Kabupaten Agam dan Kabupaten Limapuluh Kota di Provinsi Sumatera Barat. Perbedaan daerah pemberian berdasarkan atas distribusi bets vaksin yang dikirim oleh Dinas Kesehatan Provinsi Sumatera Barat sesuai dengan jumlah sasaran.

Selama tahun 2000-2012, jumlah kasus campak yang dilaporkan di dunia menurun 73\%, dari 853.480 kasus menjadi 226.722 dan insidensi penyakit campak turun 77\% dari 146 menjadi 33 kasus per juta populasi pertahun. Jumlah negara yang mengalami jumlah kasus $<5$ per juta populasi meningkat dari $55 \%$ menjadi $64 \%$. Namun, terjadi kejadian luar biasa (KLB) campak di beberapa negara termasuk Indonesia pada tahun 2012 sebanyak 15.489 kasus. Hal ini diperkirakan karena cakupan imunisasi yang menurun. Dari 12,1 juta anak yang diduga tidak memperoleh dosis pertama vaksin campak pada tahun 2012 , terdapat 13,5 juta $(64 \%)$ berada di 6 negara: India $(6,4$ juta), Nigeria $(3,8$ juta), Ethiopia (1 juta), Indonesia ( 0,9 juta), Pakistan $\left(0,7\right.$ juta), dan Kongo $(0,7$ juta $){ }^{1}$

Vaksin campak dibuat dari virus liar campak yang dilemahkan dicapai dengan beberapa kali proses kultur pada sel. Vaksin yang pertama kali dilisensi adalah vaksin Edmonston B, digunakan secara luas pada tahun 1963 hingga 1975, namun sering dihubungkan dengan timbulnya demam dan ruam. Strain Schwarz dan Moraten dibuat dari strain Edmonston, tetapi yang telah diproses lebih lanjut menjadi lebih lemah pada embrio ayam. Vaksin lain juga kemudian dikembangkan dari virus campak yang dilemahkan seperti di Rusia (strain Leningrad-16), di Tiongkok (Shanghai-19), dan di Jepang (strain CAM-70, AIK-C). Vaksin campak umumnya dalam bentuk beku kering. Di Indonesia dalam program imunisasi yang dipergunakan adalah strain CAM70, yang dikembangkan dari Jepang produksi Bio Farma. ${ }^{2,3}$

Meskipun vaksin campak produksi Bio Farma sudah lebih dari 10 tahun mendapat izin edar dari Badan Pengawas Obat dan Makanan
(BPOM), keamanan dan efektivitas vaksin tetap perlu dipantau secara berkesinambungan.

\section{Metode}

Penelitian ini mempergunakan desain kohort terhadap anak sekolah dasar (SD) di Provinsi Sumatera Barat selama periode November 2010 hingga Maret 2011. Anak sekolah dasar yang terlibat dalam penelitian ini adalah dari Kabupaten Limapuluh Kota dan Kabupaten Agam dengan pemilihan sekolah berdasarkan kesesuaian jumlah anak dan kesesuaian waktu pelaksanaan dengan Bulan Imunisasi Anak Sekolah (BIAS). Persetujuan etik telah diperoleh dari Komite Etik Penelitian Kesehatan Fakultas Kedokteran UI-RSCM, Jakarta nomor 420/PT.02/ ETIK/2010.

Minimal 150 subjek harus terlibat dalam penelitian ini setiap kelompoknya. Perhitungan jumlah subjek diambil dari sebuah studi di Sukabumi yang menghitung persentase proteksi terhadap penyakit campak setelah pemberian satu dosis vaksin campak (Bio Farma), yaitu sebesar $96 \%{ }^{4}$

Sesuai dengan program imunisasi yang ada di Indonesia, vaksin campak ini diberikan sebagai dosis boster (ulangan) pada anak-anak sekolah dasar kelas 1 . Dengan demikian, usia anak yang terlibat penelitian ini akan bervariasi karena yang menjadi acuan adalah siswa kelas 1, bukan usia. Setelah orangtua memperoleh penjelasan mengenai penelitian dan menyetujuinya dengan manadatangani formulir Persetujuan Setelah Penjelasan (PSP/informed consent) maka anak dapat ikut dalam penelitian. Anak yang berdomisili di Kabupaten Agam mendapatkan vaksin campak dengan nomor bets 250210, sedangkan anak yang berdomisili di Kabupaten Limapuluh Kota menerima vaksin campak dengan nomor bets 253080 .

Reaksi lokal dan sistemik dicatat di kartu harian pada 30 menit, 72 jam, dan hingga 28 hari setelah imunisasi. Pengamatan reaksi yang timbul dilakukan oleh orangtua dan dikonfirmasi oleh guru kelas yang sebelumnya sudah mendapatkan pelatihan mengenai penelitian ini dan cara melakukan pengamatan terhadap reaksi yang timbul.

Reaksi lokal ialah reaksi yang timbul pada dan sekitar tempatsuntikan. Reaksilokalyang diamati adalah nyeri, kemerahan dan pembengkakan pada bekas suntikan, serta reaksi lokal lainnya. Rasa nyeri dikelompokkan berdasarkan atas tingkat keparahan ringan, nyeri timbul bila 
tempat suntikan disentuh; sedang bila nyeri timbul setelah lengan digerakkan; sedangkan berat bila nyeri timbul tanpa perlakuan apa-apa. Kemerahan dan pembengkakan yang timbul diukur mempergunakan mistar dengan kategori tingkat keparahan sebagai berikut: ringan $<5 \mathrm{~cm}$, sedang 5-10 cm, dan berat $>10 \mathrm{~cm}$ dari diameter terlebar.

Reaksi sistemik adalah semua reaksi yang timbul secara sistemik pascaimunisasi. Pada literatur WHO mengenai "Supplementary Information on Vaccine Safety" dinyatakan bahwa reaksi sistemik termasuk demam, nyeri otot, dan sakit kepala. Kategori demam dibagi 3, demam ringan $38,0-38,4^{\circ} \mathrm{C}$, demam sedang $38,5-38,9^{\circ} \mathrm{C}$, dan demam berat $\geq 39^{\circ} \mathrm{C}$. Reaksi sistemik lainnya diukur berdasarkan atas intensitasnya, ringan apabila tidak mengganggu aktivitas, sedang bila terkadang mengganggu aktivitas, sedangkan berat bila menghambat aktivitas seharian. ${ }^{5}$

Untuk pemeriksaan antibodi, darah diambil praimunisasi dan juga 28 hari pascaimunisasi. Pengukuran antibodi terhadap campak dengan metode uji netralisasi yang dilakukan di laboratorium Uji Klinis Bio Farma, dengan batas proteksi $\geq 8$ titer netralisasi. Bila dikonversikan dengan referen yang digunakan maka setara dengan $\geq 200 \mathrm{mIU} / \mathrm{mL}^{6}{ }^{6,7}$ Uji netralisasi ini telah divalidasi menggunakan referen dari National Institute for Biological Standards and Control (NIBSC) nomor 66/202 dan hasil validasi telah disetujui oleh Quality Assurance PT Bio Farma. Persentase subjek yang mengalami reaksi lokal dan sistemik dihitung berdasarkan atas waktu timbulnya. Persentase subjek yang mempunyai antibodi protektif pascaimunisasi dihitung, dan geometric mean titer (GMT) yang dihasilkan dibandingkan antara praimunisasi dan pascaimunisasi. Serokonversi dinyatakan sebagai perubahan antibodi dari tidak protektif menjadi protektif pascaimunisasi. Persentase subjek yang mengalami serokonversi dihitung dan dibandingkan untuk kedua bets vaksin. Perbandingan antara praimunisasi dan pascaimunisasi tanpa melihat distribusi sampelnya. Campak yang sifatnya bebas satu sama lain serta tidak berpasangan dan variabel yang diamati merupakan variabel yang kontinu serta tipe datanya lebih tepat menggunakan uji parametrik, yaitu uji Kruskal-Wallis.

\section{Hasil}

Sejumlah 336 subjek, terdapat 166 di Kabupaten Limapuluh Kota dan 170 di Kabupaten Agam dari 13 Sekolah Dasar terlibat dalam penelitian ini. Jumlah subjek lebih dari 300 karena disesuaikan dengan jumlah murid setiap sekolah per kelas.

Karakteristik subjek menurut jenis kelamin mempunyai sebaran yang merata yaitu $50,9 \%$ laki-laki dan 49,1\% perempuan. Sebaran subjek menurut usia dapat dilihat pada Tabel 1 . Usia terbanyak adalah enam dan tujuh tahun, dengan usia rata-rata subjek 6,87 tahun.

Distribusi sampel menurut lokasi penelitian, ditemukan bahwa jumlah subjek pada kedua lokasi juga hampir sama. Berdasarkan ingatan orangtua subjek mengenai riwayat imunisasi campak, di Kabupaten Limapuluh Kota diketahui bahwa sebesar 89,8\% orangtua subjek tidak tahu mengenai riwayat imunisasi campak anaknya; $4,2 \%$ merasa belum pernah mendapat imunisasi campak; dan 6,1\% merasa pernah mendapat imunisasi campak satu kali. Adapun di Kabupaten Agam, 92,4\% orangtua subjek tidak tahu mengenai riwayat imunisasi campak anaknya, tidak ada orangtua subjek $(0 \%)$ yang merasa anaknya belum pernah mendapat imunisasi campak; dan 7,7\% pernah mendapat imunisasi campak satu kali. Namun, berdasarkan informasi dari Dinas Kesehatan Kabupaten Agam, sebagian

Tabel 1 Distribusi Usia Subjek Penelitian

\begin{tabular}{cccc}
\hline \multirow{2}{*}{ Usia (tahun) } & \multicolumn{2}{c}{ Kabupaten } & Total (n=336) \\
\cline { 2 - 4 } & $\mathbf{5 0}$ Kota $(\mathbf{n = 1 6 6 )}$ & AGAM (n=170) & 5 \\
\hline 5 & 0 & 5 & 108 \\
6 & 39 & 69 & 172 \\
7 & 104 & 68 & 34 \\
9 & 16 & 18 & 12 \\
10 & 4 & 8 & 4 \\
11 & 2 & 2 & 1 \\
\hline
\end{tabular}


Tabel 2 Kejadian Nyeri Lokal pada Tempat Suntikan Pascaimunisasi Campak di Kabupaten Limapuluh Kota

\begin{tabular}{|c|c|c|c|c|c|c|c|c|c|c|c|c|}
\hline \multirow{3}{*}{$\begin{array}{c}\text { Reaksi Nyeri } \\
\text { Lokal } \\
(n=166)\end{array}$} & \multicolumn{12}{|c|}{ Waktu dan Hasil Pengamatan } \\
\hline & \multicolumn{2}{|c|}{30 Menit } & \multicolumn{2}{|c|}{1 Hari } & \multicolumn{2}{|c|}{2 Hari } & \multicolumn{2}{|c|}{3 Hari } & \multicolumn{2}{|c|}{ 4-28 Hari } & \multicolumn{2}{|c|}{ Total } \\
\hline & $\mathbf{n}$ & $\%$ & $\mathbf{n}$ & $\%$ & $\mathbf{n}$ & $\%$ & $\mathbf{n}$ & $\%$ & $\mathbf{n}$ & $\%$ & $\mathbf{n}$ & $\%$ \\
\hline Ringan & 0 & 0,0 & 1 & 0,6 & 1 & 0,6 & 0 & 0,0 & 1 & 0,6 & 3 & 1,8 \\
\hline Sedang & 0 & 0,0 & 1 & 0,6 & 1 & 0,6 & 0 & 0,0 & 1 & 0,6 & 3 & 1,8 \\
\hline Berat & 1 & 0,6 & 0 & 0,0 & 0 & 0,0 & 0 & 0,0 & 0 & 0,0 & 1 & 0,6 \\
\hline Total & 1 & 0,6 & 2 & 1,2 & 2 & 1,2 & 0 & 0,0 & 2 & 1,2 & 7 & 4,2 \\
\hline
\end{tabular}

anak di Kabupaten Agam memperoleh vaksin campak setelah gempa melanda Sumatera Barat beberapa bulan sebelum penelitian dimulai.

Pada subjek uji di Kabupaten Agam tidak ditemukan laporan kejadian nyeri pada bekas tempat dilakukannya suntikan pascaimunisasi campak. Berdasarkan Tabel 2 terdapat kejadian nyeri pada 166 subjek di Kabupaten Limapuluh Kota. Selama pengamatan ditemukan $4,2 \%$ atau sebanyak 7 kejadian. Kejadian nyeri ringan ditemukan sebanyak $0,6 \%$ pada pengamatan hari ke-1, hari ke-2, serta hari ke-4. Kejadian nyeri sedang $0,6 \%$ juga terjadi pada pengamatan hari ke-1, hari ke-2, serta hari ke-4. Kejadian nyeri berat hanya ditemukan satu kasus $(0,6 \%)$ pada pengamatan 30 menit pascaimunisasi

Untuk reaksilokal kemerahan pada 170 subjek di Kabupaten Agam selama pengamatan tidak ditemukan, sedangkan kemerahan pada subjek di Kabupaten Limapuluh Kota dapat dilihat pada Tabel 3. Berdasarkan Tabel 3 diketahui kejadian kemerahan bekas tempat suntikan pada 166 subjek di Kabupaten Limapuluh Kota ditemukan pada pengamatan 30 menit, hari ke-1, hari ke-2, dan hari ke-3 pascaimunisasi.

Kemerahan ringan ternyata ditemukan pada pengamatan 30 menit sebanyak lima kasus $(3,0 \%)$, meningkat menjadi 17 kasus $(10,2 \%)$ pada pengamatan hari ke-1, dan selanjutnya menurun menjadi satu kasus $(0,6 \%)$ pada pengamatan hari ke-2 dan ke-3 pascaimunisasi. Adapun pada pengamatan hari ke-4 dan seterusnya tidak ditemukan kejadian kemerahan ringan. Kemerahan sedang hanya ditemukan satu kasus $(0,6 \%)$ pada pengamatan hari ke-1 pascaimunisasi. Adapun pada pengamatan hari ke-2, ke-3 dan seterusnya tidak ditemukan kejadian kemerahan sedang. Kemerahan $>10 \mathrm{~cm}$ (berat) tidak ditemukan selama pengamatan.

Berdasarkan data yang ada diketahui kejadian pembengkakan pada 170 subjek di Kabupaten Agam selama pengamatan tidak ditemukan. Pada 166 responden di Kabupaten Limapuluh Kota ditemukan pada pengamatan 30 menit dan satu hari pascaimunisasi. Pembengkakan ringan ditemukan pada pengamatan 30 menit satu kasus $(0,6 \%)$, empat kasus $(2,4 \%)$ pada hari ke-1, dan selanjutnya hilang pada pengamatan berikutnya.Pembengkakan kategori sedang dan berat tidak ditemukan selama pengamatan. Tidak ditemukan kejadian ikutan pascaimunisasi (KIPI) serius pada kedua kelompok.

Tabel 3 Kejadian Reaksi Lokal Kemerahan pada Tempat Suntikan Pascaimunisasi Campak di Kabupaten Limapuluh Kota

\begin{tabular}{|c|c|c|c|c|c|c|c|c|c|c|c|c|}
\hline \multirow{3}{*}{$\begin{array}{c}\text { Reaksi Lokal } \\
\text { Kemerahan } \\
(n=166)\end{array}$} & \multicolumn{12}{|c|}{ Waktu dan Hasil Pengamatan } \\
\hline & \multicolumn{2}{|c|}{30 Menit } & \multicolumn{2}{|c|}{1 Hari } & \multicolumn{2}{|c|}{2 Hari } & \multicolumn{2}{|c|}{3 Hari } & \multicolumn{2}{|c|}{ 4-28 Hari } & \multicolumn{2}{|c|}{ Total } \\
\hline & $\mathbf{n}$ & $\%$ & $\mathbf{n}$ & $\%$ & $\mathbf{n}$ & $\%$ & $\mathbf{n}$ & $\%$ & $\mathbf{n}$ & $\%$ & $\mathbf{n}$ & $\%$ \\
\hline Ringan & 5 & 3,0 & 17 & 10,2 & 1 & 0,6 & 1 & 0.60 & 0 & 0,0 & 24 & 14,4 \\
\hline Sedang & 0 & 0.0 & 1 & 0,6 & 0 & 0,0 & 0 & 0.00 & 0 & 0,0 & 1 & 0,6 \\
\hline Berat & 0 & 0,0 & 0 & 0,0 & 0 & 0,0 & 0 & 0.00 & 0 & 0,0 & 0 & 0,0 \\
\hline Total & 5 & 3,0 & 18 & 10,8 & 1 & 0,60 & 1 & 0,60 & 0 & 0,0 & 25 & 15,06 \\
\hline
\end{tabular}


Tabel 4 Persentase Geometric Mean Titer (GMT) di Kabupaten Agam

\begin{tabular}{lccc}
\hline \multicolumn{1}{c}{ Lokasi } & GMT (95\%IK) & GMT (95\%CI) & Nilai p \\
\hline Agam & 329,66 & 983,43 & 0,000 \\
& $(124,00-12.600,00)$ & $(521,52-15.873,00)$ & \\
Limapuluh Kota & 198,00 & 535,10 & 0,000 \\
\hline
\end{tabular}

Satuan geometric mean titres (GMT): Karber=measles=mIU/mL; Nilai $\mathrm{p}=$ nilai $\mathrm{p}$ dari post $\mathrm{t}$ dari GMT antara Karber dan $\mathrm{mIU} / \mathrm{mL}$

Kejadian demam pada 170 subjek penelitian di Kabupaten Agam selama pengamatan, yaitu demam ringan pada satu hari pascaimunisasi 2 kasus $(1,2 \%)$, sedangkan kejadian demam berat dan sedang tidak ditemukan. Kejadian demam pada 166 subjek di Kabupaten Limapuluh Kota selama pengamatan, adalah demam ringan pada 30 menit pascaimunisasi sebanyak 2 kasus $(1,2 \%)$ kejadian demam berat dan sedang tidak ditemukan.

Reaksi sistemik yang lain adalah seorang anak dengan demam, namun tidak dapat diukur mempergunakan termometer pada hari ke-14 setelah imunisasi di Kabupaten Limapuluh Kota. Di Kabupaten Agam ditemukan reaksi sistemik lainnya berupa diare pada 30 menit dan hari ke-1 pada dua anak dengan kategori ringan $(\leq 3$ kali), dan satu anak dengan pusing pada hari pertama setelah suntikan, namun semuanya sembuh spontan tanpa pengobatan.

Gambaran titer antibodi praimunisasi dan pascaimunisasi dapat dilihat pada Gambar. Dari
336 subjek yang mengikuti rekruitmen, hanya 305 yang dapat diambil darah pascaimunisasi. Dari Gambar tersebut diketahui hasil pemeriksaan serologi pascaimunisasi di Kabupaten Agam berdasarkan batas proteksi ${ }^{3} 200 \mathrm{mIU} / \mathrm{mL}$ adalah sebanyak 99 subjek $(65,6 \%)$ yang sudah protektif dan $52(33,7 \%)$ subjek di Kabupaten Limapuluh Kota yang mempunyai titer protektif. Pascaimunisasi di Kabupaten Agam, 146 (96,7\%) subjek yang mempunyai nilai antibodi protektif, sedangkan untuk Kabupaten Limapuluh Kota terdapat $149(96,8 \%)$ subjek yang mempunyai nilai antibodi yang protektif.

Terjadi peningkatan GMT dari 329,66 mIU/ $\mathrm{mL}(124,00-12.600,00)$ praimunisasi menjadi 983,43 mIU/mL (521,52-15.873,00) 28 hari pascaimunisasi, atau sebesar 2,98x di Kabupaten Agam. Di Kabupaten Limapuluh Kota terjadi peningkatan GMT dari 198,00 mIU/mL (124,00$5.000,00)$ praimunisasi menjadi $535,10 \mathrm{mIU} / \mathrm{mL}$ $(388,50-5.000,00) 28$ hari pascaimunisasi, atau sebesar 2,70 kali. Jumlah subjek yang mengalami

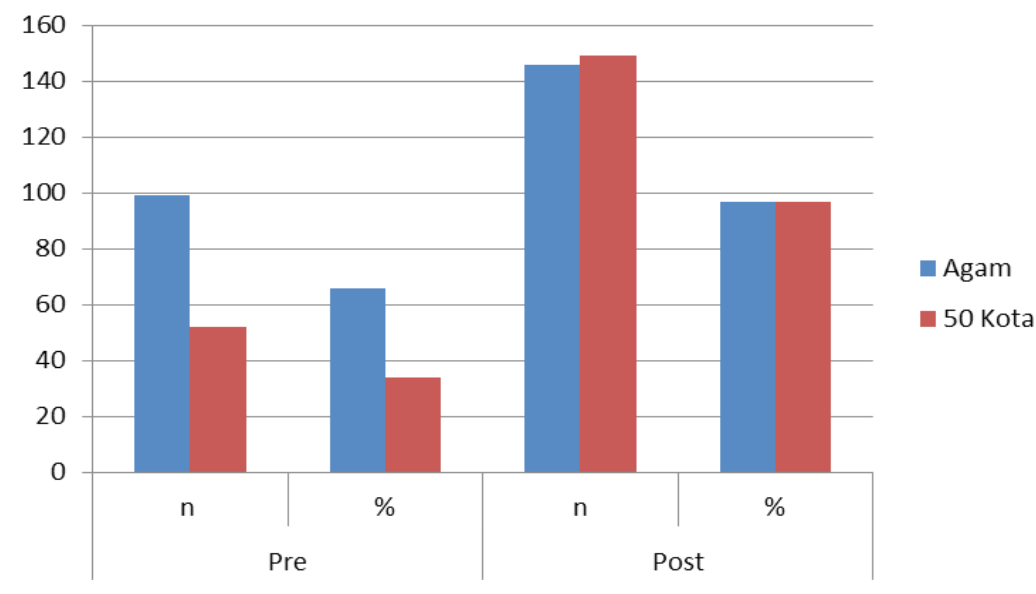

Gambar Titer Antibodi, Pra dan Pascaimunisasi 
serokonversi di Kabupaten Limapuluh Kota adalah 90,4\% dan di Kabupaten Agam adalah $95,1 \%$.

\section{Pembahasan}

Meskipun tidak dirandom, diperoleh komposisi gender yang berimbang antara kedua kabupaten. Perbandingan gender berkisar antara 46,4\% hingga $53,6 \%$. Usia subjek yang ikut dalam penelitian ini bervariasi 5-11 tahun dengan usia terbanyak adalah 6-7 tahun pada kedua kabupaten, dengan usia rata-rata adalah 6,87 tahun.

Berdasarkan atas kartu harian anak yang dibagikan di kedua kabupaten memperlihatkan profil yang sama mengenai riwayat imunisasi campak sebelumnya, lebih dari $90 \%$ subjek memilih tidak tahu untuk riwayat imunisasi campak. Namun, dari pihak Dinas Kesehatan diperoleh informasi bahwa sebagian anak di Kabupaten Agam sempat memperoleh imunisasi campak tambahan pada tahun 2009 setelah Sumatera Barat dilanda gempa. Keadaan ini yang mungkin mendasari titer yang lebih tinggi sebelum imunisasi dibanding dengan di Kabupaten Limapuluh Kota.

Reaksi lokal berupa nyeri tidak ditemukan pada anak di Kabupaten Agam. Pada pengamatan di Kabupaten Limapuluh Kota ditemukan reaksi lokal berupa nyeri ringan dan sedang sebanyak satu kasus pada hari pertama, kedua dan hari keempat, sedangkan nyeri berat ditemukan satu kasus pada pengamatan 30 menit pertama setelah imunisasi. Jumlah anak yang mengalami nyeri di Kabupaten Limapuluh Kota yang masingmasing satu kasus juga sangat kecil dibanding dengan tidak ada keluhan nyeri di Kabupaten Agam.

Reaksi lokal berupa warna kemerahan pascaimunisasi tidak ditemukan pada anak di Kabupaten Agam, sedangkan di Kabupaten Limapuluh Kota ditemukan 17 kasus $(10,2 \%)$ kemerahan ringan pada hari pertama dan menurun pada hari kedua menjadi satu kasus $(0,6 \%)$. Kemerahan sedang ditemukan pada satu kasus dan langsung hilang keesokan harinya.

Pembengkakan pada anak di Kabupaten Agam tidak ditemukan keluhan, sedangkan pada Kabupaten Limapuluh Kota ditemukan pembengkakan ringan sebanyak satu kasus pada 30 menit pascaimunisasi, meningkat menjadi 4 kasus pada hari pertama dan selanjutnya hilang. Pembengkakan kategori sedang dan berat tidak ditemukan. Perbedaan kejadian lokal antara kedua kabupaten juga tidak dapat disingkirkan akibat pengaruh daerah pengamatan yang berbeda dan petugas yang berbeda sehingga hal ini dapat menimbulkan bias. Namun, angka yang terlihat berupa reaksi lokal kemerahan yang terbesar sebanyak 10,2\% bukan angka yang signifikan besar karena pada studi PMS vaksin campak Bio Farma lainnya ditemukan kemerahan hingga $10,8 \%$, sedangkan nyeri $8,1 \%$ dan bengkak 2,7\%. ${ }^{8}$ Pada literatur dari WHO mengenai kejadian ikutan pascaimunisasi (KIPI), kejadian reaksi lokal pascaimunisasi campak memang jarang, bahkan ada yang menunjukkan angka $0-10 \%{ }^{9,10}$ Bila melihat data pasca imunisasi MMR (measles, mumps rubella), reaksi lokal baik nyeri, kemerahan maupun pembengkakan dapat ditemukan pada 17$30 \%$ subjek. ${ }^{11}$ Sebuah studi di India mengenai pemberian vaksin MMR pada usia 4-6 tahun juga menemukan reaksi lokal pada 15\% subjek penelitian. ${ }^{12}$ Dengan demikian, angka kejadian reaksi lokal yang dijumpai pada penelitian ini sudah sesuai dengan literatur WHO, namun angka ini lebih rendah bila dibanding dengan pascaimunisasi MMR.

Meskipun dua daerah ini memberikan hasil pengamatan reaksi lokal yang sama rendah, namun hasil pengamatan di Kabupaten Agam sama sekali tidak ditemukan reaksi lokal Hal ini dapat disebabkan oleh variasi tenaga imunisasi dalam tehnik menyuntik dan kemampuan dalam melakukan penilaian reaksi lokal.

Reaksi sistemik pascaimunisasi yang ditemukan adalah demam satu hari setelah imunisasi 1,2\% di Kabupaten Agam dan 1,2\% di Kabupaten Limapuluh Kota dengan klasifikasi ringan. Tidak ditemukan demam sedang dan berat. Berbeda dengan vaksin lainnya, bila dilihat pada literatur, demam akibat imunisasi campak timbul antara hari ke-8 hingga hari ke-12 pascaimunisasi dengan jumlah sekitar $2 \%$. Demam yang timbul pada waktu yang lain umumnya adalah koinsidens. ${ }^{9}$ Penelitian lain terhadap vaksin campak produksi Bio Farma pada tahun 2000, menemukan demam sebanyak $5,5 \% .{ }^{13}$ Pada penelitian ini hanya ditemukan seorang subjek mengalami demam pada hari ke14 pascaimunisasi $(0,16 \%)$. Dengan demikian, penelitian ini demam ditemukan lebih rendah daripada studi lainnya. Selain itu, pada pada penelitian ini tidak ditemukan reaksi sistemik lainnya seperti demam kejang, alergi, ruam, dan lain-lain. Ditemukan dua anak dengan diare, namun diare yang timbul segera setelah imunisasi campak tidak termasuk sebagai reaksi akibat imunisasi campak. Selama penelitian 
tidak ditemukan reaksi yang serius. Menurut literatur, KIPI serius yang dapat terjadi setelah imunisasi campak antara lain syok anafilaktik, ensefalopati, dan kejang demam. ${ }^{14}$

Dilihat dari gambaran reaksi lokal dan juga sistemik yang lebih rendah daripada angka yang ada pada literatur maka kedua bets vaksin campak ini masih menunjukkan profil yang aman dan baik. Apabila dibandingkan respons imun pada kedua kelompok, seroproteksi yang diperoleh tidak berbeda jauh, 96,69-96,75\%. Bila dibandingkan data pada saat uji klinis pada tahun 1992 lalu sangat mendekati, yaitu 96,8\%. ${ }^{6}$ Hal ini menunjukkan konsistensi vaksin campak dalam respons imun masih sangat baik. Menurut WHO, seroproteksi yang akan diperoleh pada imunisasi campak usia sekolah berkisar antara 97\% sampai 98\% dengan model skenario apapun. ${ }^{15}$ Angka ini tidak jauh berbeda dengan yang diperoleh pada studi ini.

Serokonversi yang diperoleh pada studi ini adalah berkisar antara 90,38\% hingga 95,1\%. Bila dibanding dengan literatur, serokonversi untuk boster vaksin campak di negara berkembang pada kelompok usia 4-6 tahun adalah 72,6\%, lebih rendah dari yang diperoleh pada penelitian ini. ${ }^{12}$ Hal ini menunjukkan bahwa kedua bets vaksin campak memberikan respons imun yang baik. Kendala pada penelitian ini adalah karena diadakan di dua kabupaten yang berbeda dengan jarak yang cukup jauh, menyebabkan kesulitan dalam koordinasi di lapangan. Kendala lainnya adalah kapasitas tenaga kesehatan yang juga bervariasi antara kedua daerah, meskipun hal ini sudah diminimalisasi dengan pemberian pelatihan sebelumnya.

Simpulan, kedua bets vaksin campak yang diamati masih menunjukkan profil yang aman dan respons imun yang baik pada anak sekolah.

\section{Ucapan Terima Kasih}

Ucapan terima kasih kepada Dinas Kesehatan Kabupaten Agam dan Kabupaten Limapuluh Kota beserta jajaran atas kerjasama yang sangat baik hingga tingkat puskesmas. Ucapan terima kasih juga atas kerjasama guru-guru dan murid-murid di 13 Sekolah Dasar yang ikut berpartisipasi dalam penelitian ini di wilayah Kabupaten Agam dan Kabupaten Limapuluh Kota.

\section{Daftar Pustaka}

1. World Health Organization. Global control and regional elimination of measles 20002012. WER. 2014;89(6):45-52.

2. World Health Organization. The Immunological basis for immunization series. Module 7: Measles Update. 2009. 2009:1-34.

3. Strebel PM, Papania MJ, Dayan GH, Halsey NA. Measles Vaccine. Dalam: Vaccines. Edisi ke-5. USA: Saunders-Elsevier. 2009: hlm. 353-98.

4. Yayasan Indonesia Sejahtera. Field Trial of CAM-70 Bio Farma (BF) measles vaccine in Sukabumi, West Java, Indonesia. 1992.

5. Food and Drug Administration. Guidance for Industry: toxicity grading scale for healthy adult and adolescent volunteers Preventive Vaccine Trials. 2007:1-10.

6. Cohen BJ, Audet S, Andrews N, Beeler J. Plaque reduction neutralization test for measles antibodies: description of a standardized laboratory method for use in immunogenicity studies of aerosol vaccination. Vaccine. 2007;26(1):59-66.

7. Cohen BJ, Doblas D, Andrews N. Comparison of plaque reduction neutralization and measles specific IgG ELISA for assessing immunogenicity of measles vaccination. Vaccine. 2008;26(50):6392-7.

8. Fadlyana E, Rusmil K, Dhamayanti M, Bordisetianto E, Bachtiar NS, Tandrihastuti. Reactogenicity of Bio Farma vaccine used in Routine National Immunization Programme. Bandung: Bagian Anak RSHS; 2008.

9. World Health Organization. Supplementary information on vaccine safety. Part 2: Background rates of adverse events following immunization; 2000. WHO; 2000.

10. World Health Organization. Vaccine safety basic e-learning course. Module 3. 2015: Tersedia dari: http://vaccine-safety-training. org/vaccine-reactions.html.

11. World Health Organization. Information sheet observed rate of vaccine reactions, measles, mumps and rubella vaccine. 2014:1-11.

12. Gomber S, Arora SK, Das S dan Ramachandran VG. Immune response to second dose of MMR vaccine in Indian children. Indian J Med Res. 2011;134(3):302-6.

13. Yuwono D, Suharyono W, Julitasari, Mulyanti Priyanto, Heriyanto B, Sukmara U. Penelitian vaksin campak CAM-70 produksi Bio Farma pada bayi 9-11 bulan. Pokja Campak \& Balitbangkes; 2000.

14. Departemen Kesehatan Republik Indonesia. Pedoman pemantauan dan penanggulangan 
Julitasari: Aspek Kualitas Protektivitas, Reaksi Lokal dan Sistemik Pascaimunisasi dengan Vaksin Campak (Bio Farma)

kejadian ikutan pasca imunisasi. Jakarta: Depkes RI; 2005:42-3.

15. Lee MS, Nokes DJ. Predicting and comparing long-term measles antibody profiles of different immunization policies. Bull WHO. 2001; 79(7):615-24. 